\title{
Bdellovibrio and Like Organisms are Predictors of Microbiome Diversity in distinct Host Groups
}

\author{
Julia Johnke ${ }^{1}$, Sebastian Fraune ${ }^{2}$, Thomas Bosch², Ute Hentschel ${ }^{3,4}$, and
} Hinrich Schulenburg ${ }^{1^{\star}}$

${ }^{1}$ Department of Evolutionary Ecology and Genetics, Zoological Institute, CAU Kiel, Am Botanischen Garten 1-9, 24118 Kiel, Germany

2Department of Cell and Developmental Biology, Zoological Institute, CAU Kiel, Am Botanischen Garten 1-9, 24118 Kiel, Germany

${ }^{3}$ RD3 Marine Microbiology, GEOMAR Helmholtz Centre for Ocean Research Kiel, Düsternbrooker Weg 20, 24105 Kiel, Germany.

${ }^{4}$ Section of Marine Biology, CAU Kiel, Am Botanischen Garten 1-9, 24118 Kiel, Germany.

\section{* Correspondence:}

Hinrich Schulenburg

hschulenburg@zoologie.uni-kiel.de

+494318804141

Keywords: biodiversity, predator, prey, microbiome, Bdellovibrio

The nucleotide sequence data reported are available in the EMBL databases under the accession number PRJEB30476. 


\begin{abstract}
Biodiversity is generally believed to be a main determinant of ecosystem functioning. This principle also applies to the microbiome and could consequently contribute to host health. According to ecological theory, communities are shaped by top predators whose direct and indirect interactions with community members cause stability and diversity. Bdellovibrio and like organisms (BALOs) are a neglected group of predatory bacteria that feed on Gram-negative bacteria and can thereby influence microbiome composition. We asked whether BALOs can predict biodiversity levels in microbiomes from distinct host groups and environments. We demonstrate that genetic signatures of BALOs are commonly found within the 16S rRNA reads from diverse host taxa. In many cases, their presence, abundance, and especially richness are positively correlated with overall microbiome diversity. Our findings suggest that BALOs can act as drivers of microbial alpha-diversity and should therefore be considered as candidates for the restoration of microbiomes and the prevention of dysbiosis.
\end{abstract}


Biodiversity is a key attribute of productive [1] and stable ecosystems [2]. This is likely due to the activity of highly productive keystone species [3], which are often more common in species-rich communities [1]. Nevertheless, productivity and stability appear to be mainly driven by diversity itself and not by individual taxa [4]. Speciesrich communities exist for example in the human gut and oral microbiome and are usually assumed to consist of functionally redundant species that act as insurance in case of extinctions $[5,6]$. Consequently, species-rich communities are more resilient (cf. [7]). To date, most studies on the effect of biodiversity on ecosystem functioning and specifically the effect of microbiome composition on host health have focused on a single trophic level. Yet, changes in the diversity of one trophic level can affect other trophic levels, either directly through consumer-resource interactions or indirectly when the decrease of one species leads to abundance changes of other species [8]. The presence of top predators has particularly strong effects because they can limit dominant species abundance and thereby free niches for rare taxa [9-11]. The impact of predators is likely distinct from environmental stressors, which may similarly free niches and subsequently increase microbiome diversity, as recently documented for the microbiome of Daphnia waterfleas after antibiotic exposure [12]. Yet, in this case, the effect on community composition is likely to be random, whereas predators usually target the dominant species.

Bdellovibrio and like organisms (BALOs) are obligate predators of Gram-negative bacteria in a wide range of habitats $[13,14]$. BALOs were recently linked to a healthy human gut microbiome [15], and proposed as living antibiotics in medical treatment [16] and water remediation [17]. Additionally, a microcosm experiment showed that their predatory activity can exceed phage-induced mortality [18]. We here draw attention to this neglected group of predators and tested their association with microbial diversity as an indicator of a healthy microbiome across distinct animal host groups and environments.

We analyzed 16S rRNA data from randomly chosen, exemplary host taxa that are representative of distinct animal taxonomic groups, including early branching metazoans, ecdysozoa, selected vertebrates, and additionally home surfaces (Table S1 and Supplementary Methods). We only considered studies, if they included samples with and without BALOs, thereby allowing us to determine the consequences of BALO presence and absence in comparable groups. We determined BALO occurrence (although not necessarily activity) by identifying OTUs that showed $97 \%$ sequence identity to members of the BALO-containing taxonomic groups Bdellovibrionales (including the families Bacteriovoracaceae and Bdellovibrionaceae) and Micavibrionales (including Micavibrionaceae). From these data, we inferred relative BALO abundance and corresponding microbiome alpha- (i.e., ShannonWiener diversity, Simpson's diversity, richness) and beta-diversities.

The presence of BALOs was associated with a significantly higher Simpson and Shannon diversity for the microbiomes of seven and five host species, respectively, as well as the home surfaces (Figure 1, Table S2). The main exceptions referred to two sponge species, Carteriospongia foliascens and Ircinia variabilis, which showed a significantly higher alpha-diversity in the absence of BALOs. This negative association was not observed for microbiome richness (Figure S1, Table S3). Our subsequent analysis of absolute OTU numbers revealed that microbiome richness is significantly associated with both BALO abundance (Figure 2a, Table S4) and BALO richness (Figure 2b, Table S4) in case of $H$. vulgaris and the sponges. A trend toward this association was additionally observed for $N$. vectensis and $D$. melanogaster. 
Interestingly, for both host systems, OTU richness was highest with medium BALO abundance, which possibly indicates that BALO richness rather than abundance influences microbiome richness.

(a)

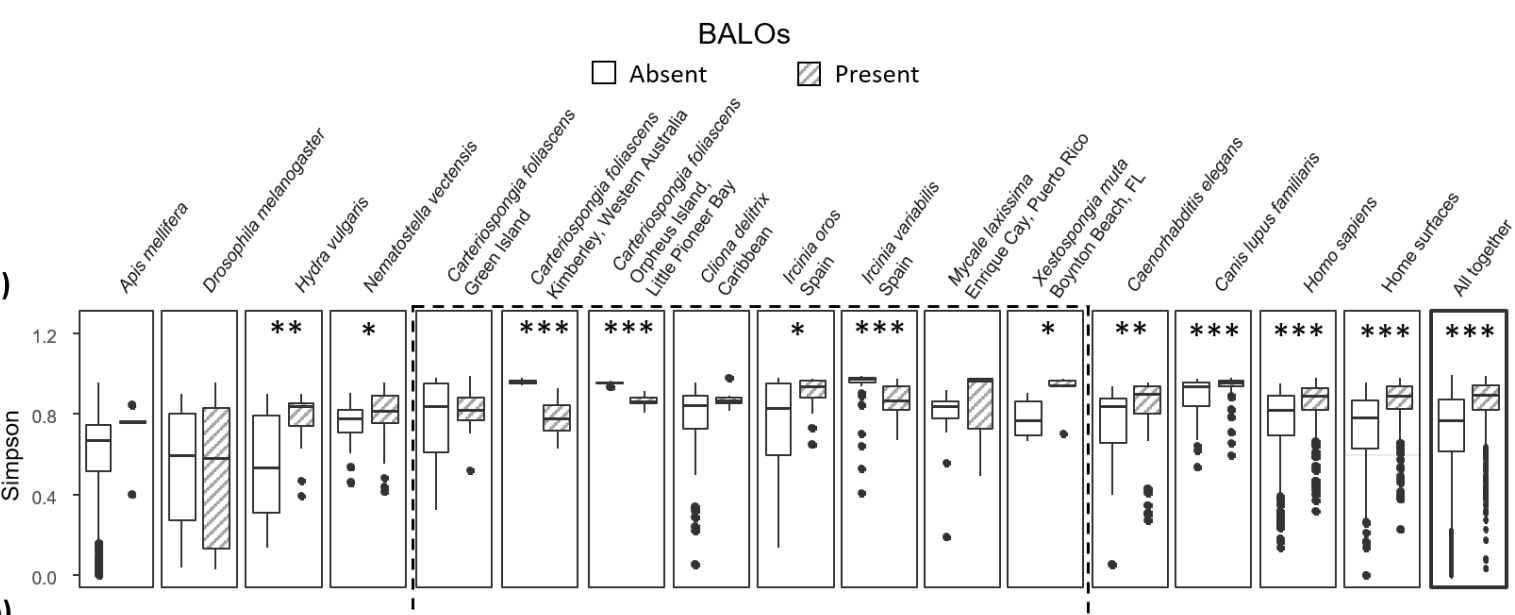

(b)

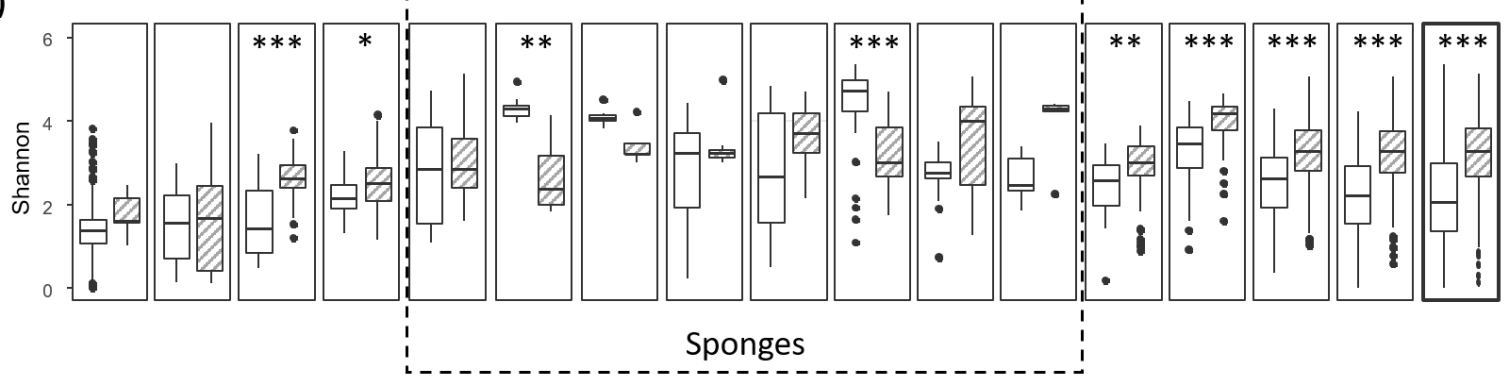

Fig. 1. Microbiome alpha-diversity in the presence and absence of BALOs. The Simpson (a) and Shannon (b) diversity is shown for a set of different hosts. Significant differences are indicated by asterisks and were calculated using the Wilcoxon rank sum test. P-values: $p<0.001:^{: * * * \prime}, 0.0011>p<0.01:^{(* *)}, 0.011>p<0.00^{:(* \prime}$. P-values are given in the Table S2. 
(a)

(b)

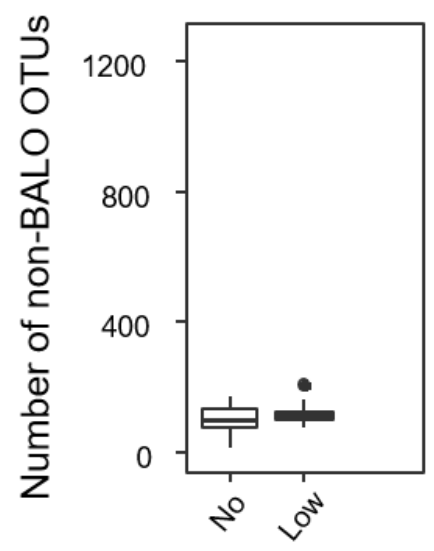

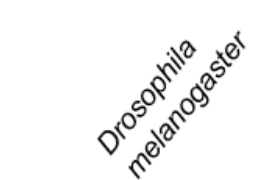
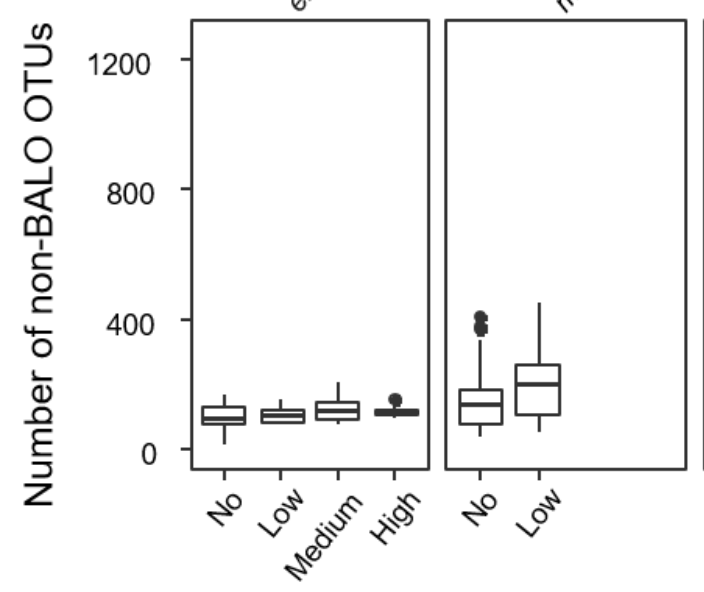
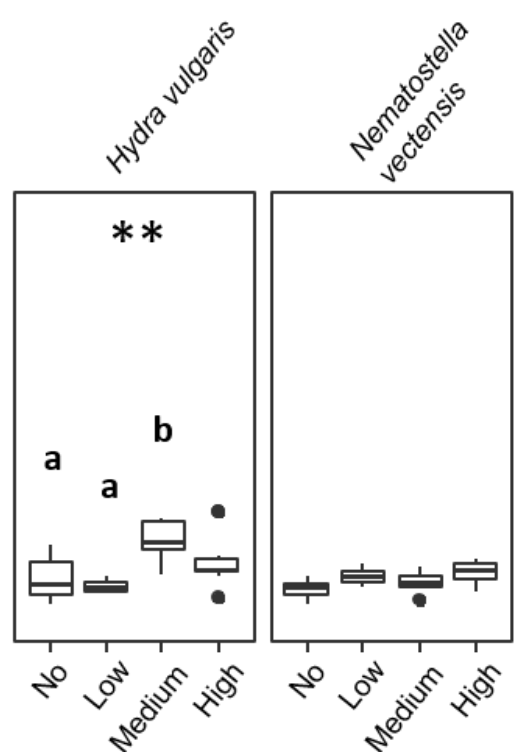

BALO abundance

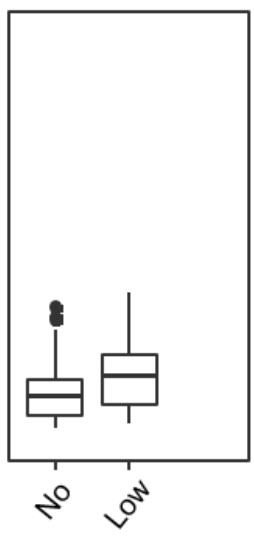

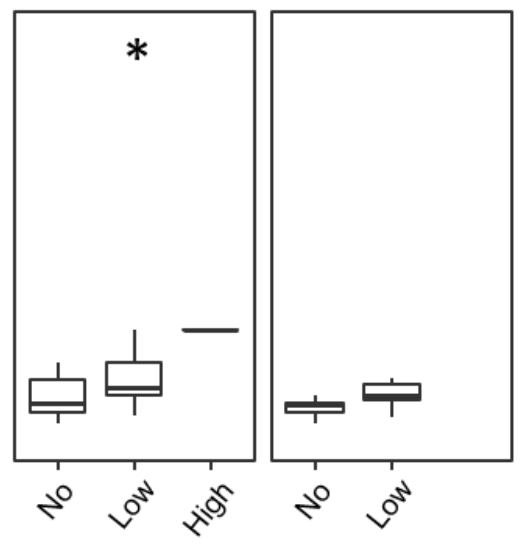

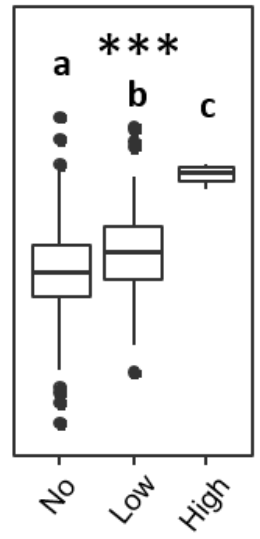

BALO richness

Fig. 2. Host microbiome richness measured as number of different non-BALO OTUs with increasing BALO abundance (a) and BALO richness (b). Significant differences are indicated by asterisks and were calculated using the Kruskal-Wallis rank sum test. P-values: $p<0.001:^{(* * *)}, 0.0011>p<0.01:^{(* *)}, 0.011>p<0.05^{:(*)}$. Significant differences between single categories of BALO abundance and BALO richness are indicated by different letters and were calculated with Dunn's post hoc test. All P-values are given in the Table S4.

In contrast, variation in microbiome beta-diversity was not linked to the BALOs (Figure 3 ). At the same time, our PCoA analysis indicated an influence of BALOs on sample clustering for several hosts (especially cnidarians and C. elegans). However, the clustering was not independent of sample type, making it impossible to infer the exact cause of clustering from the current data.

To exclude that BALO presence is caused by high microbiome diversity as a consequence of sampling effects, we analyzed the complete sponge dataset, additionally including species without BALOs [19]. We found that alpha-diversity per se does not predict the presence of BALOs (Table S5 and S6), which is therefore unlikely caused by sampling effects alone. 
(a)

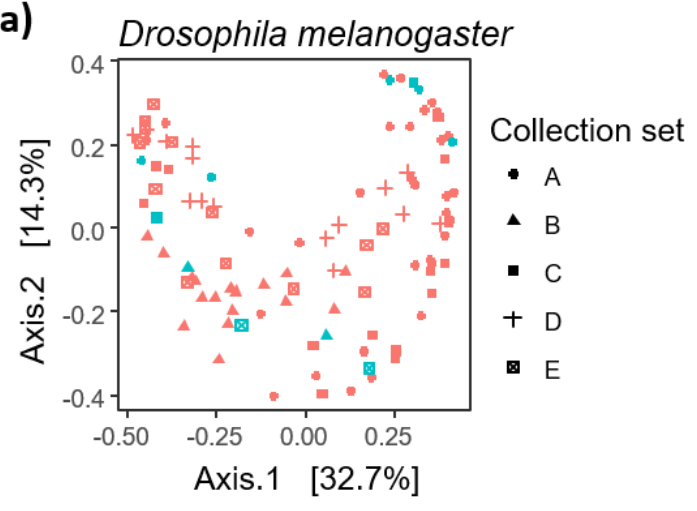

(c)

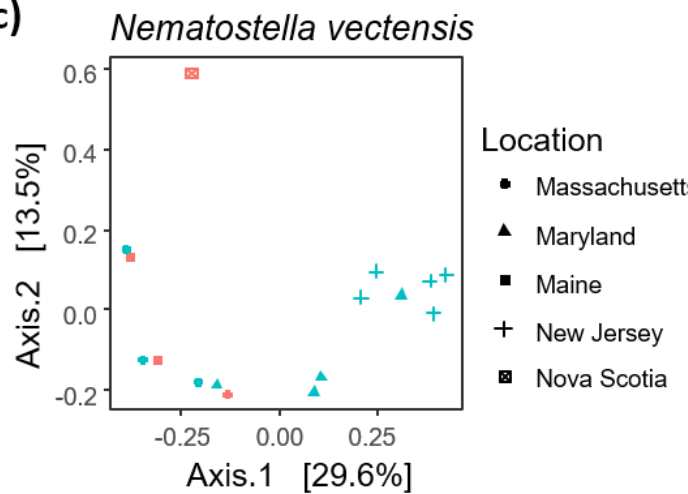

(b)

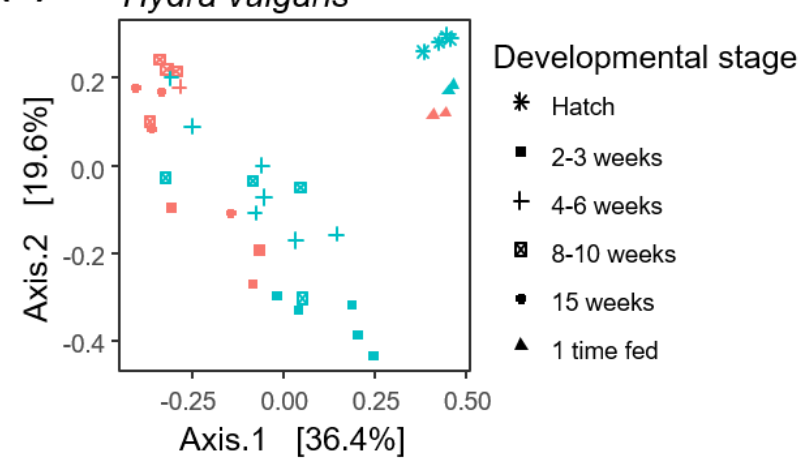

(d) Caenorhabditis elegans

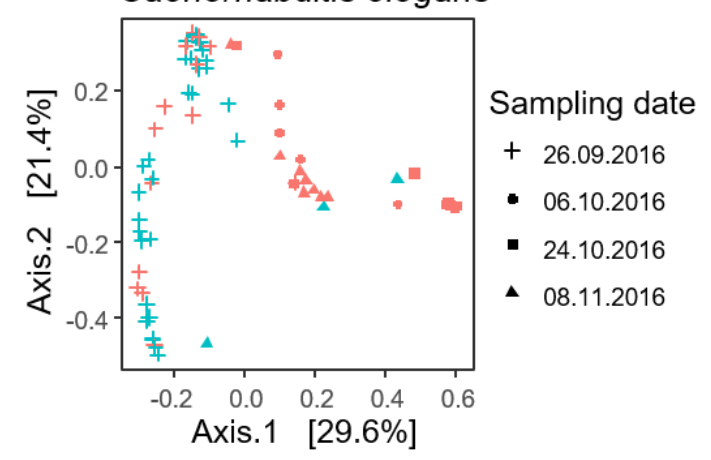

(e) All sponges together

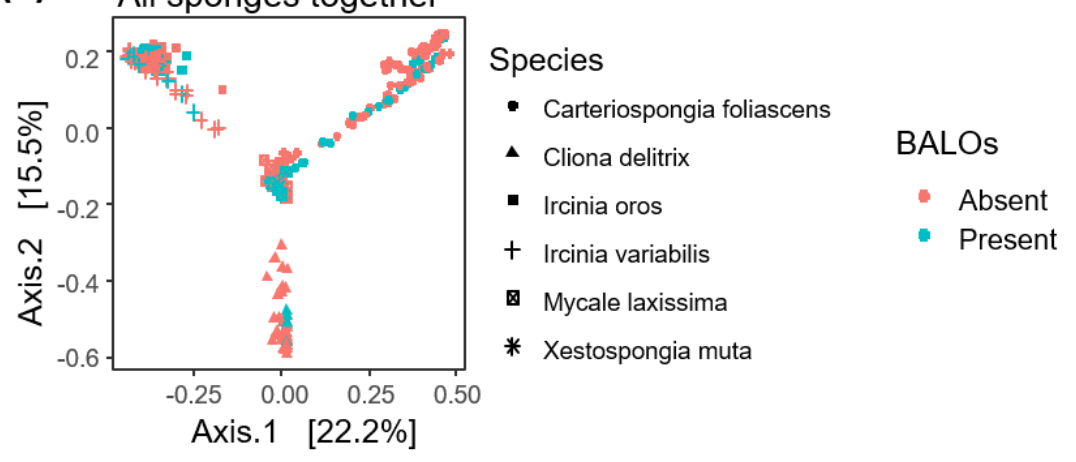

Fig. 3. PCoA of microbiome samples from different hosts using Bray Curtis distances. Samples are color-coded by presence and absence of BALOs. Different shapes indicate different sample subsets as indicated by the respective legends.

The loss of top predators has comprehensive effects on community structure $[9,10]$. We tested this idea by comparing microbiome alpha-diversities for distinct animal hosts and environments that either lacked or contained a prominent group of microbial predators, the BALOs. With the exception of the considered insects and most sponge species, we found that microbiomes containing BALOs were characterized by a significantly higher alpha-diversity.

In contrast to the overall results, two sponge species showed a negative correlation between BALO presence and microbiome diversity, although not when considering microbiome richness. These results may suggest that BALO-containing sponges harbor a more species-rich, but less even microbiome. Notably, sponges in general 
possess a comparatively species-rich microbiome (Figure S1). In these cases, evenness may be negatively correlated to richness, consistent with previous observations for plant communities [20] and possibly due to sampling effects, where a superior competitor is more likely present in species-rich communities [1]. A nichepreemption model was previously identified to be the best predictor for the patterns in plant communities [20]. Niche-preemption should favor resource use plasticity among the less competitive species, resulting in lower growth and consequently reduced evenness. In case of the sponges, the negative richness-evenness-relationship might then overshadow the effect of BALOs on microbiome diversity. Temporal effects could additionally explain the higher sponge microbiome diversity in the absence of BALOs. As the sponge data used in this study came from single time point samples, we cannot exclude subsequent changes in the community structure, for example a delayed effect of BALO loss or gain on microbiome diversity. However, the longitudinal data on surface microbiomes [21] indicates that changes in BALO presence/absence are associated with more or less simultaneously occurring changes in OTU richness (Fig. S2).

We found that BALO OTU richness, rather than abundance, is significantly associated with microbiome richness in $H$. vulgaris and the combined set of sponges. Moreover, this significant association between BALO and microbiome richness was only observed when the high BALO richness category could be included. Considering that different BALO strains are known to vary in their range of suitable prey [22], the above results may suggest that a more diverse BALO community is able to prey on a more diverse set of bacteria and thereby reduces the predation pressure on single species, thus increasing microbiome diversity.

Our additional analysis of beta-diversity did not reveal a strong BALO influence on microbiome community structure. Together with the results on alpha-diversity, this may imply that BALO presence is not correlated with a specific community composition and that BALOs survive in a range of differently assembled communities.

Our results from a range of distinct animal hosts and environments point to BALOs as potential drivers of microbiome alpha-diversity, possibly by actively preying on highly abundant species, thereby favoring rare species. Thus, BALOs may be of particular importance for our understanding of the stability and resilience of microbiome ecosystem functions. Our current meta-analysis is, however, based on associations, which can only be indicative of possible causal relationships. An important next step should therefore be a detailed experimental analysis of the exact causal role of BALOs on microbiome diversity and resulting functions. It would be of similar high interest to assess to what extent other kinds of bacterial antagonists, such as phages, or environmental stressors may also influence microbiome diversity and the associated effects. Moreover, it is worth testing whether the interaction between BALOs and other bacteria is additionally shaped by the host immune system, which could cause different dynamics of the BALO-mediated effects within rather than outside host organisms.

Considering that BALOs are not pathogenic to higher organisms [23], have a likely stronger effect on community structure than phages [18], and appear to enhance microbial diversity, they are highly promising candidates for probiotic therapy [24] that aims at restoring disturbed microbiomes and improving host health or ecosystem productivity and stability.

\section{Acknowledgement}


We are grateful for advice from members of the Schulenburg group and the Collaborative Research Center CRC1182 on Origin and Function of Metaorganisms. This work was funded by the CRC1182, projects A4 and B2.

\section{Conflict of interest statement}

The authors declare no conflict of interest.

\section{References}

1. Cardinale BJ, Srivastava DS, Duffy JE, et al (2006) Effects of biodiversity on the functioning of trophic groups and ecosystems. Nature 443:989-992. https://doi.org/10.1038/Nature05202

2. Boyer KE, Kertesz JS, Bruno JF Biodiversity effects on productivity and stability of marine macroalgal communities: the role of environmental context. Oikos 118:1062-1072. https://doi.org/10.1111/j.1600-0706.2009.17252.x

3. Power ME, Tilman D, Estes JA, et al (1996) Challenges in the quest for keystones. BioScience 46:609-620. https://doi.org/10.2307/1312990

4. Thompson R, Starzomski BM (2007) What does biodiversity actually do? A review for managers and policy makers. Biodivers Conserv 16:1359-1378. https://doi.org/10.1007/s10531-005-6232-9

5. Naeem S, Li SB (1997) Biodiversity enhances ecosystem reliability. Nature 390:507-509. https://doi.org/10.1038/37348

6. Yachi S, Loreau M (1999) Biodiversity and ecosystem productivity in a fluctuating environment: The insurance hypothesis. Proc Natl Acad Sci 96:14631468. https://doi.org/10.1073/pnas.96.4.1463

7. Holling CS (1973) Resilience and stability of ecological systems. Annu Rev Ecol Syst 4:1-23. https://doi.org/10.1146/annurev.es.04.110173.000245

8. Thebault E, Loreau M (2003) Food-web constraints on biodiversity-ecosystem functioning relationships. Proc Natl Acad Sci U S A 100:14949-14954. https://doi.org/10.1073/pnas.2434847100

9. Jabiol J, McKie BG, Bruder A, et al Trophic complexity enhances ecosystem functioning in an aquatic detritus-based model system. J Anim Ecol 82:10421051. https://doi.org/10.1111/1365-2656.12079

10. Gessner MO, Swan CM, Dang CK, et al (2010) Diversity meets decomposition. Trends Ecol Evol 25:372-380. https://doi.org/10.1016/j.tree.2010.01.010

11. Leitão RP, Zuanon J, Villéger S, et al (2016) Rare species contribute disproportionately to the functional structure of species assemblages. Proc $\mathrm{R}$ Soc B Biol Sci 283:20160084. https://doi.org/10.1098/rspb.2016.0084 
12. Callens $\mathrm{M}$, Watanabe $\mathrm{H}$, Kato $\mathrm{Y}$, et al (2018) Microbiota inoculum composition affects holobiont assembly and host growth in Daphnia. Microbiome 6:. https://doi.org/10.1186/s40168-018-0444-1

13. Sockett RE (2009) Predatory lifestyle of Bdellovibrio bacteriovorus. Annu Rev Microbiol 63:523-539. https://doi.org/10.1146/annurev.micro.091208.073346

14. Rotem O, Pasternak Z, Jurkevitch E (2014) Bdellovibrio and like organisms. In: Rosenberg E, DeLong EF, Lory S, et al (eds) The Prokaryotes. Springer Berlin Heidelberg, Berlin, Heidelberg, pp 3-17

15. lebba V, Santangelo F, Totino V, et al (2013) Higher prevalence and abundance of Bdellovibrio bacteriovorus in the human gut of healthy subjects. Plos One 8: https://doi.org/10.1371/journal.pone.0061608

16. Negus D, Moore C, Baker M, et al (2017) Predator versus pathogen: How does predatory Bdellovibrio bacteriovorus interface with the challenges of killing Gram-negative pathogens in a host setting? Annu Rev Microbiol 71:441-457. https://doi.org/10.1146/annurev-micro-090816-093618

17. Kandel PP, Pasternak Z, van Rijn J, et al (2014) Abundance, diversity and seasonal dynamics of predatory bacteria in aquaculture zero discharge systems. FEMS Microbiol Ecol 89:149-161. https://doi.org/10.1111/1574-6941.12342

18. Chen H, Laws EA, Martin JL, et al (2018) Relative Contributions of Halobacteriovorax and Bacteriophage to Bacterial Cell Death under Various Environmental Conditions. mBio 9:e01202-18. https://doi.org/10.1128/mBio.01202-18

19. Thomas T, Moitinho-Silva L, Lurgi M, et al (2016) Diversity, structure and convergent evolution of the global sponge microbiome. Nat Commun 7:11870. https://doi.org/10.1038/ncomms 11870

20. Zhang H, John R, Peng Z, et al (2012) The relationship between species richness and evenness in plant communities along a successional gradient: $\mathrm{A}$ study from sub-alpine meadows of the eastern Qinghai-Tibetan plateau, China. PLoS ONE 7:. https://doi.org/10.1371/journal.pone.0049024

21. Jurkevitch E, Minz D, Ramati B, Barel G (2000) Prey range characterization, ribotyping, and diversity of soil and rhizosphere Bdellovibrio spp. isolated on phytopathogenic bacteria. Appl Env Microbiol 66:2365-71

22. Gupta S, Tang C, Tran M, Kadouri DE (2016) Effect of Predatory Bacteria on Human Cell Lines. PLOS ONE 11:e0161242. https://doi.org/10.1371/journal.pone.0161242

23. Dwidar M, Monnappa AK, Mitchell RJ (2012) The dual probiotic and antibiotic nature of Bdellovibrio bacteriovorus. BMB Rep 45:71-78. https://doi.org/10.5483/BMBRep.2012.45.2.71

24. Mortzfeld BM, Urbanski S, Reitzel AM, et al (2016) Response of bacterial colonization in Nematostella vectensis to development, environment and 
biogeography. Environ Microbiol 18:1764-1781. https://doi.org/10.1111/14622920.12926

25. Adair KL, Wilson M, Bost A, Douglas AE (2018) Microbial community assembly in wild populations of the fruit fly Drosophila melanogaster. ISME J 12:959-972. https://doi.org/10.1038/s41396-017-0020-x

26. Song SJ, Lauber C, Costello EK, et al (2013) Cohabiting family members share microbiota with one another and with their dogs. eLife 2:e00458. https://doi.org/10.7554/eLife.00458

27. Lax S, Smith DP, Hampton-Marcell J, et al (2014) Longitudinal analysis of microbial interaction between humans and the indoor environment. Science 345:1048-1052. https://doi.org/10.1126/science.1254529

28. Franzenburg S, Fraune S, Altrock PM, et al (2013) Bacterial colonization of Hydra hatchlings follows a robust temporal pattern. ISME J 7:781-790. https://doi.org/10.1038/ismej.2012.156 


\section{Supplementary Material}

\section{Bdellovibrio and Like Organisms are Predictors of Microbiome Diversity across Diverse Host Groups} Julia Johnke1, Sebastian Fraune ${ }^{2}$, Thomas Bosch², Ute Hentschel ${ }^{3,4}$, and Hinrich Schulenburg ${ }^{1^{*}}$

${ }^{1}$ Department of Evolutionary Ecology and Genetics, Zoological Institute, CAU Kiel, Am Botanischen Garten 1-9, 24118 Kiel, Germany

${ }^{2}$ Department of Cell and Developmental Biology, Zoological Institute, CAU Kiel, Am Botanischen Garten 1-9, 24118 Kiel, Germany

${ }^{3}$ RD3 Marine Microbiology, GEOMAR Helmholtz Centre for Ocean Research Kiel, Düsternbrooker Weg 20, 24105 Kiel, Germany.

${ }^{4}$ Section of Marine Biology, CAU Kiel, Am Botanischen Garten 1-9, 24118 Kiel, Germany.

* Corresponding author: Hinrich Schulenburg

hschulenburg@zoologie.uni-kiel.de

\section{$1 \quad$ Supplementary Methods}

For our analysis, we randomly selected exemplary host taxa that are representative of distinct taxonomic animal groups, ranging from very simple to more complex hosts and including early branching invertebrates, ecdysozoa, and also vertebrates (Table S1). In addition, we only considered host taxa, for which a single study included at least five samples with and without BALOs - with the exception of the Nematostella dataset with only four samples without BALOs. This preselection was performed in order to allow a direct comparison of samples with and without BALOs for each host system or environment. Further, only studies with publicly available OTU tables were selected. Moreover, we considered one study with longitudinal data generated from human mucus, sebum, skin swabs, as well as from different surfaces from their family homes [10]. This data set served to test the stability of the association of BALO presence and bacterial community diversity across time within the same environment.

Several datasets were from microbiomeDB (http://microbiomedb.org $/ \mathrm{mbio} /$ ) and only included relative abundance data, while the remaining data sets also had information on absolute frequencies. The Caenorhabditis elegans dataset was produced by us for this study by sampling worms from the Kiel Botanical garden in 2016 at four consecutive time points (one in October, two in September, and one in November). Worm samples were prepared as described previously [1] by using the protocol for "natural worm" microbiome extraction. DNA was sequenced using the Miseq platform and the primers $515 f-806 r$ to sequence the V4 region of the 16S rRNA gene. Original sequence data are available from the European Nucleotide Archive (accession number PRJEB30476). Sequence reads were analyzed using Mothur v. 1.39 .5 [2] as described in the Miseq SOP (https://www.mothur.org/wiki/MiSeq_SOP) and the SILVA reference database version 128 . OTU clustering was based on $97 \%$ sequence identity. Samples with BALOs were categorized based on their abundance (i.e., high (11-227 reads), medium (6-10), low (1-5), and no reads) and richness (high (5-7), low (1-4), and no). We compared microbiome alpha-diversity in the presence and absence of BALOs using twosample Wilcoxon rank sum tests to account for outliers. We assessed the influence of BALO abundance or richness on microbiome richness with the Kruskal-Wallis rank sum test and Dunn's post hoc test with $p$-value adjustment using fdr. Beta-diversity was measured using Bray Curtis distance on relative abundance and visualized using PCoA of the 500 most abundant OTUs. Sponge samples were analyzed using Fisher's exact test and the Wilcoxon rank sum test to test for an association between BALO presence/absence and microbiome alpha-diversity, either as categorical or continues variable. All statistical analyses were performed in $\mathrm{R}$ [3] using phyloseq [4] and vegan [5]. 
2 Supplementary Figures and Tables

340 Table S1: Summary of the considered and analyzed studies.

\begin{tabular}{|c|c|c|c|c|c|c|}
\hline Study & $\begin{array}{l}\text { Host body } \\
\text { site }\end{array}$ & $\begin{array}{l}\text { Seq. } \\
\text { platform }\end{array}$ & $\begin{array}{l}\text { Environment } \\
\text { of host }\end{array}$ & $\begin{array}{l}\mathbf{N} \\
\text { samples }\end{array}$ & $\begin{array}{l}\text { Normaliz } \\
\text { ation }\end{array}$ & $\begin{array}{l}\text { Further } \\
\text { information }\end{array}$ \\
\hline \multicolumn{7}{|c|}{ Caenorhabditis elegans (Nematoda) } \\
\hline This study ${ }^{\star}$ & Gut & $\begin{array}{l}\text { Miseq } \\
\text { (V4) }\end{array}$ & $\begin{array}{l}\text { Natural isolates } \\
\text { from compost } \\
\text { heaps }\end{array}$ & 73 & $\begin{array}{l}4986 \\
\text { reads per } \\
\text { sample }\end{array}$ & Time series \\
\hline \multicolumn{7}{|c|}{ Nematostella vectensis (Cnidaria) } \\
\hline [6] & $\begin{array}{l}\text { Whole } \\
\text { animals }\end{array}$ & $454(\mathrm{~V} 2)$ & $\begin{array}{l}\text { Natural isolates, } \\
\text { but maintained } \\
\text { in the lab for } 10 \\
\text { years as clonal } \\
\text { lines }\end{array}$ & 16 & $\begin{array}{l}3000 \\
\text { reads per } \\
\text { sample }\end{array}$ & $\begin{array}{l}\text { Microbiome } \\
\text { diversity of species } \\
\text { sampled along the } \\
\text { US east coast }\end{array}$ \\
\hline \multicolumn{7}{|c|}{ Six sponge species } \\
\hline [7] & $\begin{array}{l}\text { Random } \\
\text { sponge } \\
\text { pieces }\end{array}$ & $\begin{array}{l}\text { Hiseq } \\
\text { (V4) }\end{array}$ & $\begin{array}{l}\text { Natural isolates } \\
\text { from different } \\
\text { sites }\end{array}$ & $\begin{array}{l}315 \\
\text { samples }\end{array}$ & $\begin{array}{l}\text { No } \\
\text { normaliza } \\
\text { tion }\end{array}$ & $\begin{array}{l}\text { Different species } \\
\text { and different } \\
\text { sampling sites }\end{array}$ \\
\hline \multicolumn{7}{|c|}{ Drosophila melanogaster (Insecta, Diptera) } \\
\hline [8] & Whole flies & $\begin{array}{l}\text { Miseq } \\
\text { (V3-V4) }\end{array}$ & $\begin{array}{l}\text { Samples taken } \\
\text { from various } \\
\text { kitchen }\end{array}$ & 79 & $\begin{array}{l}1200 \\
\text { reads per } \\
\text { sample }\end{array}$ & Only adult flies \\
\hline \multicolumn{7}{|c|}{ Apis mellifera (Insecta, Hymenoptera) } \\
\hline $\begin{array}{l}\text { Unpublished, } \\
\text { Dominguez- } \\
\text { Bello }\end{array}$ & $\begin{array}{l}\text { whole } \\
\text { head, } \\
\text { whole } \\
\text { larva, } \\
\text { whole } \\
\text { pupa, } \\
\text { whole gut }\end{array}$ & Unknown & Unknown & 383 & Unknown & $\begin{array}{l}\text { From } \\
\text { microbiomeDB, } \\
\text { different functional } \\
\text { guilds and } \\
\text { developmental } \\
\text { stages, effect of } \\
\text { Tetracycline } \\
\text { application }\end{array}$ \\
\hline \multicolumn{7}{|c|}{ Canis Iupus familaris (Vertebrata, Mammalia) } \\
\hline [9] & Sebum & $\begin{array}{l}\text { Illumina } \\
\text { GAIlx } \\
\text { (V2) }\end{array}$ & Different homes & 145 & $\begin{array}{l}5000 \\
\text { reads per } \\
\text { sample }\end{array}$ & $\begin{array}{l}\text { From } \\
\text { microbiomeDB, } \\
\text { most BALOs in } \\
\text { sebum und mucus }\end{array}$ \\
\hline \multicolumn{7}{|c|}{ Home surfaces } \\
\hline [10] & $\begin{array}{l}\text { Different } \\
\text { surfaces } \\
\text { from family } \\
\text { homes }\end{array}$ & $\begin{array}{l}\text { Hiseq } \\
\text { (V4) }\end{array}$ & Different homes & 690 & $\begin{array}{l}2500 \\
\text { reads per } \\
\text { sample }\end{array}$ & $\begin{array}{l}\text { From } \\
\text { microbiomeDB }\end{array}$ \\
\hline \multicolumn{7}{|c|}{ Homo sapiens (Vertebrata, Mammalia) } \\
\hline [10] & $\begin{array}{l}\text { Mucus, } \\
\text { sebum, } \\
\text { skin swabs }\end{array}$ & $\begin{array}{l}\text { Hiseq } \\
\text { (V4) }\end{array}$ & Different homes & 910 & $\begin{array}{l}2500 \\
\text { reads per } \\
\text { sample }\end{array}$ & $\begin{array}{l}\text { From } \\
\text { microbiomeDB }\end{array}$ \\
\hline \multicolumn{7}{|c|}{ Hydra vulgaris (Cnidaria) } \\
\hline [11] & $\begin{array}{l}\text { Whole } \\
\text { animals }\end{array}$ & $\begin{array}{l}454 \text { (V1- } \\
\text { V2) }\end{array}$ & $\begin{array}{l}\text { Lab-kept } \\
\text { animals }\end{array}$ & 36 & $\begin{array}{l}\text { No } \\
\text { normaliza } \\
\text { tion }\end{array}$ & $\begin{array}{l}\text { Developmental } \\
\text { data }\end{array}$ \\
\hline
\end{tabular}


343 Table S2: Test statistics of the comparison of microbiome alpha-diversity in the absence and 344 presence of BALOs as shown in Fig. 1.

\begin{tabular}{|c|c|c|c|}
\hline $\begin{array}{l}\text { diversity } \\
\text { measure }\end{array}$ & host & W & $\mathbf{P}$ \\
\hline Simpson & Apis mellifera & 594 & 0.1541 \\
\hline Simpson & Caenorhabditis elegans & 774 & 0.001617 \\
\hline Simpson & Canis lupus familaris & 1382 & $<0.001$ \\
\hline Simpson & Drosophila melanogaster & 506 & 0.9089 \\
\hline Simpson & Homo sapiens & 57463 & $<0.001$ \\
\hline Simpson & Nematostella vectensis & 736 & 0.03724 \\
\hline Simpson & Family homes & 27095 & $<0.001$ \\
\hline Simpson & Hydra vulgaris & 68 & $<0.001$ \\
\hline Simpson & Carteriospongia foliascens_Green Island & 91 & 0.589 \\
\hline Simpson & Carteriospongia foliascens_Kimberley, Western Australia & 48 & $<0.001$ \\
\hline Simpson & Carteriospongia foliascens_Orpheus Island, Little Pioneer Bay & 50 & $<0.001$ \\
\hline Simpson & Cliona delitrix_Caribbean & 140 & 0.3135 \\
\hline Simpson & Ircinia oros_Spain & 148 & 0.01725 \\
\hline Simpson & Ircinia variabilis_Spain & 425 & $<0.001$ \\
\hline Simpson & Mycale laxissima_Enrique Cay, Puerto Rico & 35 & 0.1653 \\
\hline Simpson & Xestospongia muta_Boynton Beach, FL & 5 & 0.04798 \\
\hline Simpson & All together & 486490 & $<0.001$ \\
\hline Shannon & Apis mellifera & 557 & 0.1151 \\
\hline Shannon & Caenorhabditis elegans & 792 & 0.0025 \\
\hline Shannon & Canis lupus familaris & 1019 & $<0.001$ \\
\hline Shannon & Drosophila melanogaster & 487 & 0.9348 \\
\hline Shannon & Homo sapiens & 49350 & $<0.001$ \\
\hline Shannon & Nematostella vectensis & 729 & 0.0327 \\
\hline Shannon & Family homes & 22200 & $<0.001$ \\
\hline Shannon & Hydra vulgaris & 58 & $<0.001$ \\
\hline Shannon & Carteriospongia foliascens_Green Island & 85 & 0.4231 \\
\hline Shannon & Carteriospongia foliascens_Kimberley, Western Australia & 45 & 0.004662 \\
\hline Shannon & Carteriospongia foliascens_Orpheus Island, Little Pioneer Bay & 41 & 0.05528 \\
\hline Shannon & Cliona delitrix_Caribbean & 159 & 0.6025 \\
\hline Shannon & Ircinia oros_Spain & 185 & 0.1247 \\
\hline Shannon & Ircinia variabilis_Spain & 417 & $<0.001$ \\
\hline Shannon & Mycale laxissima_Enrique Cay, Puerto Rico & 35 & 0.1653 \\
\hline Shannon & Xestospongia muta_Boynton Beach, FL & 6 & 0.07323 \\
\hline Shannon & All together & 415580 & $<0.001$ \\
\hline
\end{tabular}


346 Table S3: Test statistics of the comparison of microbiome richness in the presence and 347 absence of BALOs as shown in Fig. S1.

\begin{tabular}{lll}
\hline Host & W & P \\
\hline Caenorhabditis elegans & 178.5 & 0.06802 \\
\hline Drosophila melanogaster & 348 & 0.1102 \\
\hline Hydra vulgaris & 88.5 & 0.003041 \\
\hline Nematostella vectensis & 11 & 0.1293 \\
\hline All sponges together & 4531.5 & $<0.001$ \\
\hline Carteriospongia foliascens_Green Island & 144 & $<0.001$ \\
\hline Carteriospongia foliascens_Kimberley, Western Australia & 70 & 0.9321 \\
\hline Carteriospongia foliascens_Orpheus Island, Little Pioneer Bay & 116 & 0.4946 \\
\hline Cliona delitrix_Caribbean & 468 & 0.021 \\
\hline Ircinia oros_Spain & 518 & $<0.001$ \\
\hline Ircinia variabilis_Spain & 664 & 0.01112 \\
\hline Mycale laxissima_Enrique Cay, Puerto Rico & 220 & 0.9319 \\
\hline Xestospongia muta_Boynton Beach, FL' & 42 & 0.1058 \\
\hline
\end{tabular}


349 Table S4: Test statistics of the comparison of microbiome richness and BALO abundance 350 and BALO richness as shown in Fig. 2.

\begin{tabular}{|c|c|c|c|c|c|}
\hline host & category & $\begin{array}{l}\text { Kruskal-Wallis } \\
\text { Chi-squared }\end{array}$ & Df & $\mathbf{P}$ & Significant Dunn's \\
\hline $\begin{array}{l}\text { Caenorhabditis } \\
\text { elegans }\end{array}$ & $\begin{array}{l}\text { BALO } \\
\text { abundance }\end{array}$ & 3.3508 & 1 & 0.06717 & \\
\hline $\begin{array}{l}\text { Drosophila } \\
\text { melanogaster }\end{array}$ & $\begin{array}{l}\text { BALO } \\
\text { abundance }\end{array}$ & 6.3712 & 3 & 0.09488 & \\
\hline Hydra vulgaris & $\begin{array}{l}\text { BALO } \\
\text { abundance }\end{array}$ & 12.795 & 3 & 0.005102 & $\begin{array}{l}\text { Medium:Low } P=0.014 \\
\text { No:Medium } P=0.011\end{array}$ \\
\hline $\begin{array}{l}\text { Nematostella } \\
\text { vectensis }\end{array}$ & $\begin{array}{l}\text { BALO } \\
\text { abundance }\end{array}$ & 3.7776 & 3 & 0.2865 & \\
\hline $\begin{array}{l}\text { All sponges } \\
\text { together }\end{array}$ & $\begin{array}{l}\text { BALO } \\
\text { abundance }\end{array}$ & 14.573 & 3 & 0.002221 & No:Low $P=0.0033$ \\
\hline $\begin{array}{l}\text { Caenorhabditis } \\
\text { elegans }\end{array}$ & $\begin{array}{l}\text { BALO } \\
\text { diversity }\end{array}$ & 4.2926 & 3 & 0.2316 & \\
\hline $\begin{array}{l}\text { Drosophila } \\
\text { melanogaster }\end{array}$ & $\begin{array}{l}\text { BALO } \\
\text { diversity }\end{array}$ & 2.5684 & 1 & 0.109 & \\
\hline Hydra vulgaris & $\begin{array}{l}\text { BALO } \\
\text { diversity }\end{array}$ & 6.7652 & 2 & 0.03396 & \\
\hline $\begin{array}{l}\text { Nematostella } \\
\text { vectensis }\end{array}$ & $\begin{array}{l}\text { BALO } \\
\text { diversity }\end{array}$ & 2.489 & 1 & 0.1146 & \\
\hline $\begin{array}{l}\text { All sponges } \\
\text { together }\end{array}$ & $\begin{array}{l}\text { BALO } \\
\text { diversity }\end{array}$ & 17.87 & 2 & $<0.001$ & $\begin{array}{l}\text { No:Low } P=0.0032 \text {, No:High } P= \\
0.0053 \text {, Low:High } P=0.0349\end{array}$ \\
\hline
\end{tabular}


352 Table S5: Test statistics of the comparison of sponge microbiome alpha-diversity category 353 and BALO presence. Contingency tables are based on the average of the respective value 354 (given in brackets for the different categories) for each species.

\begin{tabular}{lcccc}
\hline & \multicolumn{2}{c}{ Microbiome richness $^{\mathbf{a}}$} & \multicolumn{2}{c}{ Fisher's Exact Test } \\
& high $(>=600-809.25)$ & low $(306.67-<600)$ & $P$ & Odds ratio \\
\hline BALOs present & 10 & 38 & 0.7356 & 0.79247 \\
BALOs absent & 4 & 12 & &
\end{tabular}

\begin{tabular}{lcccc}
\hline & \multicolumn{2}{c}{ Microbiome Simpson diversity } & \multicolumn{2}{c|}{ Fisher's Exact Test } \\
\hline & high $(>=0.9)$ & low $(0.38-<0.9)$ & $P$ & Odds ratio \\
\hline BALOs present & 17 & 31 & 1 & 1.20297 \\
BALOs absent & 5 & 11 & & \\
\hline
\end{tabular}

\begin{tabular}{lcccc}
\hline & \multicolumn{2}{c}{ Microbiome Shannon diversity } & \multicolumn{2}{c}{ Fisher's Exact Test } \\
\hline & high $(3.5-4.74)$ & low $(1.7-<3.5)$ & P & Odds ratio \\
\hline BALOs present & 23 & 25 & 1 & 1.17976 \\
BALOs absent & 7 & 9 & & \\
\end{tabular}

355 a Microbiome richness is treated as a categorical variable, being either high or low. Cut-offs 356 for the two groups are indicated. 
358 Table S6: Wilcoxon rank sum test statistics of the comparison of sponge microbiome alpha359 diversity in samples either with BALO presence versus BALO absence.

\begin{tabular}{lll}
\hline Diversity measure $^{\mathrm{a}}$ & W & $\mathbf{P}$ \\
\hline Simpson & 324 & 0.3598 \\
\hline Shannon & 329 & 0.4018 \\
\hline OTU richness & 364 & 0.7647 \\
\hline
\end{tabular}

360 aicrobiome diversity is used as a continuous variable and compared among the two 361 groups, which are either defined by the presence or the absence of BALOs. 


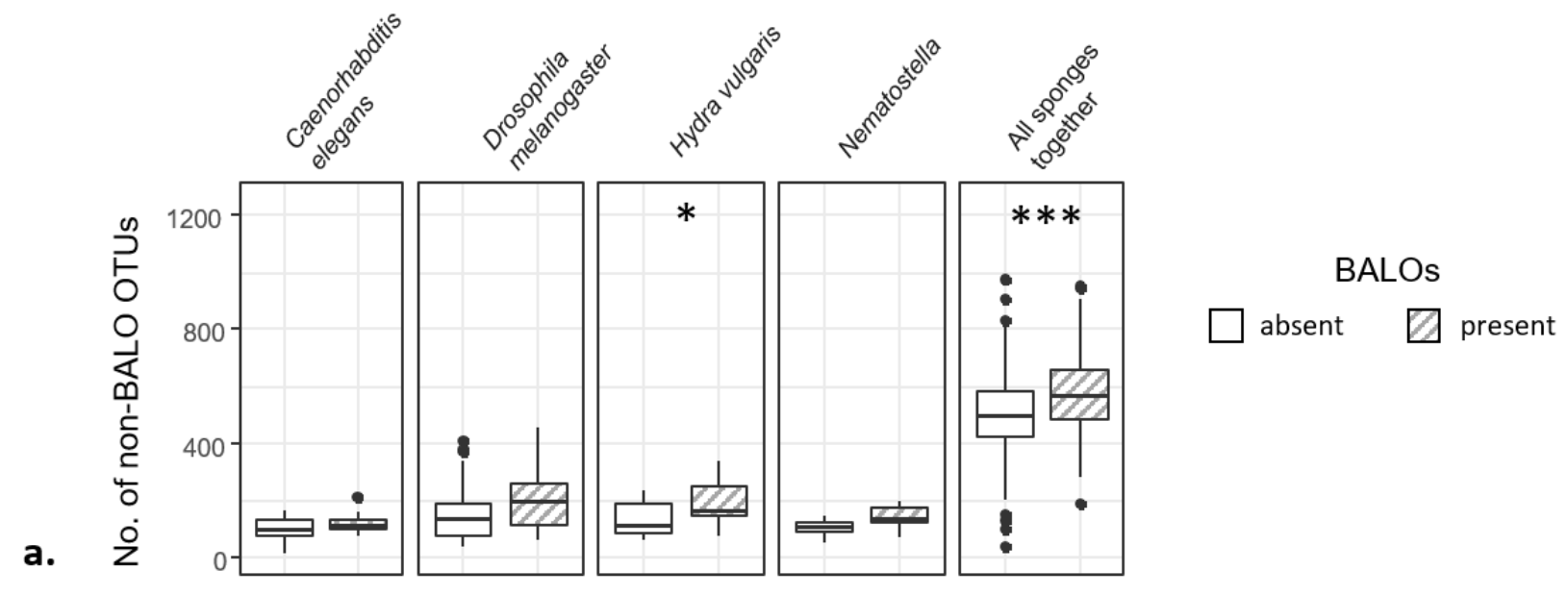

b. $\frac{0}{z}$

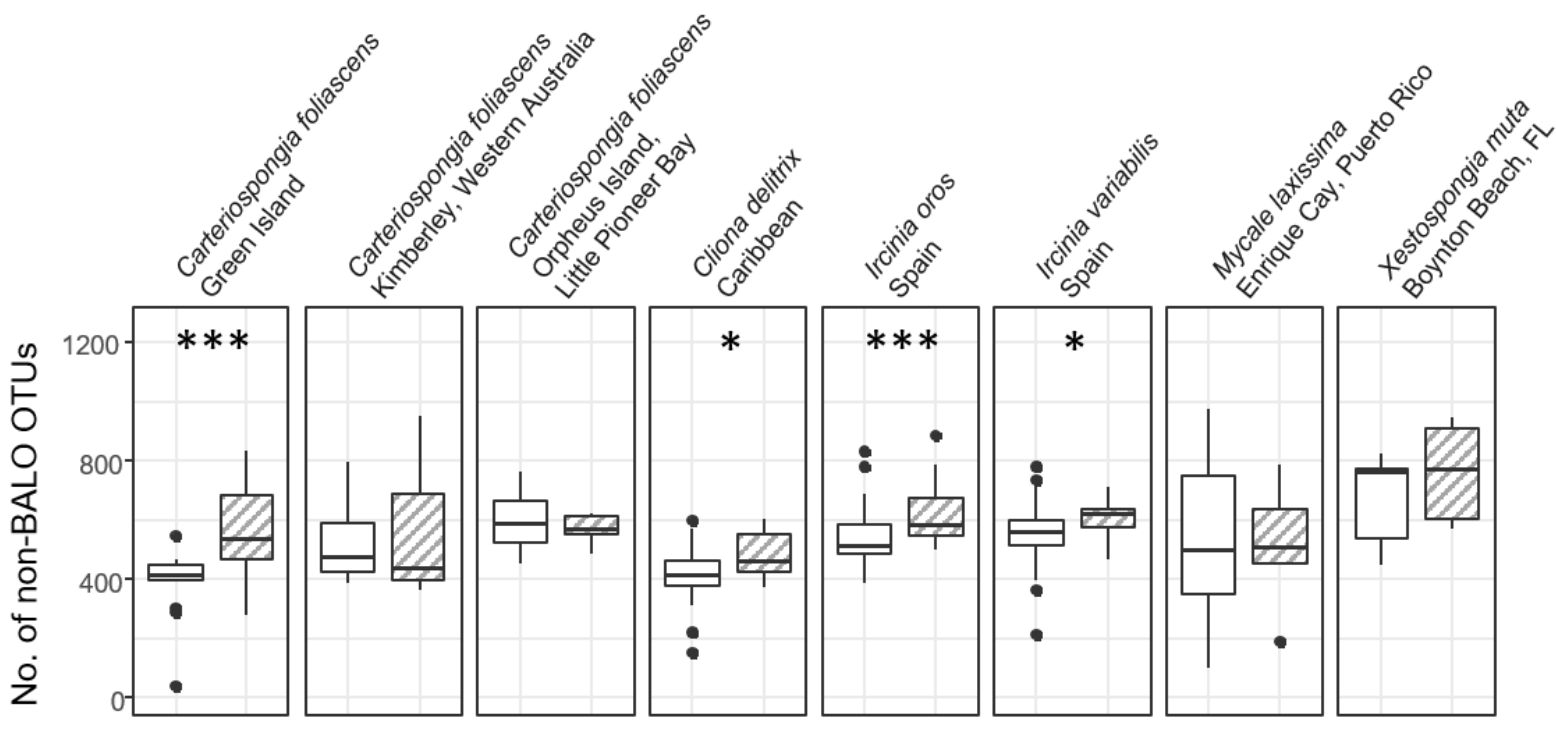

Fig. S1: Microbiome richness of different hosts (a) and particular sponge species (b) measured as number of different non-BALO OTUs in the presence and absence of BALOs. Significant differences are indicated by asterisks and were calculated using the Wilcoxon rank sum test. P-values: $p<0.001:^{(* \star *)}, 0.0011>p<0.01:^{(* *)}, 0.011>p<0.05:^{(* *}$. P-values are given in the Table S3. 

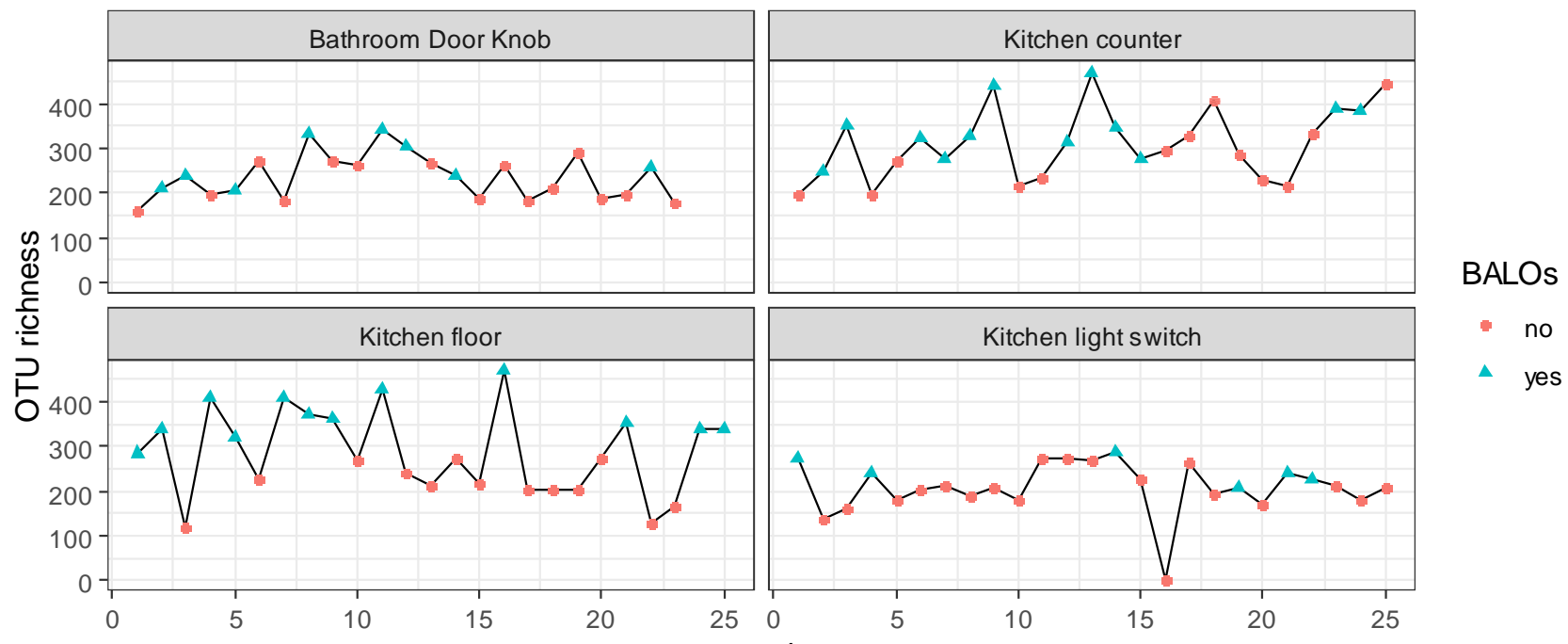

Fig. S2: Microbiome richness of longitudinal samples from house 05b from [10]. Samples were taken every other day. Data points are colored and shaped according to the presence 375 or absence of BALOs. 


\section{Supplementary References}

1. Dirksen P, Marsh SA, Braker I, et al (2016) The native microbiome of the nematode Caenorhabditis elegans: gateway to a new host-microbiome model. BMC Biol 14:1-16. https://doi.org/10.1186/s12915-016-0258-1

2. Schloss PD, Westcott SL, Ryabin T, et al (2009) Introducing mothur: open-source, platform-independent, community-supported software for describing and comparing microbial communities. Appl Environ Microbiol 75:7537-7541. https://doi.org/10.1128/Aem.01541-09

5. Dixon $P$ (2003) VEGAN, a package of $R$ functions for community ecology. J Veg Sci 14:927-930. https://doi.org/10.1111/j.1654-1103.2003.tb02228.x

6. Mortzfeld BM, Urbanski S, Reitzel AM, et al (2016) Response of bacterial colonization in Nematostella vectensis to development, environment and biogeography. Environ Microbiol 18:1764-1781. https://doi.org/10.1111/1462-2920.12926

7. Thomas T, Moitinho-Silva L, Lurgi M, et al (2016) Diversity, structure and convergent evolution of the global sponge microbiome. Nat Commun 7:11870. https://doi.org/10.1038/ncomms11870

8. Adair KL, Wilson M, Bost A, Douglas AE (2018) Microbial community assembly in wild populations of the fruit fly Drosophila melanogaster. ISME J 12:959-972. https://doi.org/10.1038/s41396-017-0020-x

9. Song SJ, Lauber C, Costello EK, et al (2013) Cohabiting family members share microbiota with one another and with their dogs. eLife 2:e00458.

https://doi.org/10.7554/eLife.00458

10. Lax S, Smith DP, Hampton-Marcell J, et al (2014) Longitudinal analysis of microbial interaction between humans and the indoor environment. Science 345:1048-1052. https://doi.org/10.1126/science.1254529

11. Franzenburg S, Fraune S, Altrock PM, et al (2013) Bacterial colonization of Hydra hatchlings follows a robust temporal pattern. ISME J 7:781-790. https://doi.org/10.1038/ismej.2012.156 